\title{
Diurnal Fluctuations of Heart Rate and Locomotive Activity in the Vole (Microtus arvalis)
}

\author{
Keiji ISHII, Masayoshi KUWAHARA, Hirokazu TSUBONE, \\ and Shigeru SUGANO \\ Department of Comparative Pathophysiology, Faculty of Agriculture, The \\ University of Tokyo, 1-1-1 Yayoi, Bunkyo-ku, Tokyo 113, Japan
}

(Received 22 May 1992/Accepted 4 August 1992)

\begin{abstract}
Diurnal fluctuations of heart rate and locomotive activity were observed in the unanesthetized and unrestrained voles (Microtus arvalis) and mice, and the differences in these biological characters between voles and mice were also investigated. The mean heart rate of vole in whole day was lower than that of mice. In voles, there were no significant differences in the mean heart rate between in light period and in dark period. It was observed that most of voles were active in not only dark period but light period. On the other hand, in mice, the mean heart rate in dark period was significantly higher than that in light period, and the nocternal habit was shown obviously in the locomotive activity. In voles, the ultradian rhythmicities of $95-210 \mathrm{~min}$ in the heart rate and those of $160-210 \mathrm{~min}$ in the locomotive activity were recognized, and the fluctuations of heart rate due to ultradian rhythmicity in voles exceeded the difference between the heart rate in light period and that in dark period. In mice, one of three animals showed the ultradian rhythmicity of $85 \mathrm{~min}$ in the fluctuation of heart rate. Diurnal fluctuation of the heart rate in voles consisted of the two patterns which the peaks of heart rate were coincident with the active period or the resting period. However, all the peaks of heart rate in mice were coincident with the active period. These results suggested that the fluctuations of heart rate in voles were dependent on ultradian rhythmicities in addition to the circadian rhythmicities. - KEY WORDS : biological rhythm, heart rate, locomotive activity, telemetry, vole
\end{abstract}

\section{ハタネズミ（Microtus arvalis）の心拍数 および自発運動の日内変動}

\author{
石井圭司・桑原正貴・局 博一・菅野 茂
}

東京大学農学部比較病態生理学教室

\footnotetext{
ハタネズミは草食性に適した消化管の形態を有し ている点に注目され, 現在実験動物化が進められて いる小型邫歯類である。以前よりハ夕ネズミの生態 学的な研究が各方面でなされているが, 生理学的な 特性についても多くの関心がもたれている[3,6,13， $14]$ 。

その主な研究成果として, 古くから数多くの研究 者により，野生状態および実験室環境下における八
}

タネズミの自発運動リズムには数時間周期のウルト ラディアンリズムが存在することが報告されている [8]。しかし心機能の日内変動りズムに関する詳細 な報告は未だなされていない。

今回著者らはハ夕ネズミの心拍数のリズム性を明 らかにする目的で，無拘束下のハ夕ネズミおよびマ ウスの心電図と自発運動をテレメーターシステムを 用いて連続記録し, 日内変動の詳細な解析を行った。 


\section{材料および方法}

被験動物：実験にはハンガリ一原産のハタネズミ (Microtus arvalis) 5 匹（体重 $42.0 \sim 52.2 \mathrm{~g}, 8$ ～14 力月柃, \#V 1 \# \# 5 ) およびマウス $(\mathrm{ICR} \cdot \mathrm{Jcl})$ 3 匹(体重 $46.2 \sim 47.8 \mathrm{~g}, 4$ 力月柃, \#M 1 \#M 3 ) でいずれも成熟雄個体を用いた。ハ夕ネズミは日本 獣医畜産大学獣医生理化学教室のクローズドコロ ニー由来のものを自家繁殖して使用した。

心電困および自発運動の記録：記録に先立ってぺ ントバルビタール $(50 \mathrm{mg} / \mathrm{kg}$ i.p.) による麻醉下 で, 動物の頸背部の皮䖉を切開し, 当該皮下に小動 物用テレメーター送信器（プライムテック社製, TA $10 \mathrm{EA}-\mathrm{F} 2$ またはTA $10 \mathrm{ETA}-\mathrm{F} 2$ ) を埋め 込んだ。記録電極は胸部の皮下を這わせ, 電極先端 を胸骨柄付近および剣状軟骨付近にそれぞれ位置さ せ，胸部双極誘導心電困を記録できるようにした。 手術の終了後は動物が麻酔状態から完全に覚醒する まで保温管理した。なお抗生物質等の術後投与は行 わなかった。

心電龱記録は手術からの回復の目的で術後 3 日間 にわたり通常飼育した後に行った。テレメーター送 信器から発信されるAM電波を受信器（プライム テック社製, RA 1610)で受信し, 受信器内で増幅さ れたアナログ心電図波形をECGプロセッサー(秼) フトロン製）に入力した。入力された心電四は10： 00 から 5 分ごとに 4 秒間の波形をフロッピーディ スク上に自動記録した。拍数の計測にあたっては, ECGプロセッサーの解析編集機能を用いてノイズ, アーティファクトの影響を除いた後に心拍数を算出 した。記録は 3 日（\#V 1）ないし 4 日間（\#V 2 \# V 5,\#M 1 \#M 3 ) 継続して行った。

心電困記録と同時に自発運動の記録を振動感知法 によって行った。すなわち，4個のゴムボール上に アクリル板を設置し，その上にケージを置いた。ア クリル板上にはスプリングによる振動スイッチを取 り付け, 動物の自発運動による振動をスイッチ信号 に変換し, 自家製のインターフェイスを介してパー ソナルコンピューター（NEC製，PC-9801 VM）に とりこみ, 10 分間当たりのカウント数を計測した。 以上述べた実験装置全体の構成図をFig. 1 に示し た。

記録中の動物は通常飼育に用いているケージ
$(175 \times 245 \times 140 \mathrm{~mm})$ 内で餌と水を不断給与し， 14 $\mathrm{L} ： 10 \mathrm{D}$ （6：00〜20：00 明期）の明暗環境下で個 別飼育した。

心拍数リズムおよび自発運動りズムの周期性解析 はカイ自乗ピリオドクラム法 [12］に基づいて行っ た。

測定值は平均値士標準偏差で示し, 有意差検定は t-test, 周期性の検定はカイ自乗検定法により行っ た。

\section{成}

1)平均心拍数：テレメトリー計測による 24 時間, 明期および暗期の平均心拍数のそれぞれの值を個体 ごとにTable 1 に示した。

24 時間の平均心拍数はハタネズミが $441 \pm 31$ 回/ 分, マウスは $615 \pm 34$ 回/分であった。一方, 明期の 平均心拍数はハタネズミが $436 \pm 33$ 回/分, マウスは $591 \pm 35$ 回/分であり，暗期の平均心拍数はハ夕ネズ ミが $448 \pm 29$ 回/分, マウスは $648 \pm 32$ 回/分であっ た。明期および暗期の平均心拍数を比較すると，八 夕ネズミの場合 5 例中 3 例で暗期の方が有意に多 かったが，マウスは全例において暗期の方が有意に 多かった。

八タネズミとマウスを比較すると，24 時間，明期 および暗期平均心拍数のいずれにおいてもハ夕ネズ ミはマウスに比へて少ない傾向にあった。

2)心拍数と自発運動量の 24 時間にわたる变動： 24 時間にわたるハ夕ネズミおよびマウスの心拍数 と自発運動量の変動のパターンをそれぞれFig. 2 およびFig. 3 に示した。

ハ夕ネズミでは全例において心拍数および自発運 動量はともに短時間周期の日内変動を示した。その 周期における心拍数の增減の振幅は，明期と暗期に おける平均心拍数の差よりも大きい傾向が認められ た (Fig. 2 )。

マウスでは全例において暗期に心拍数, 自発運動 量ともに増加し, 総じて明期には低下するという夜 行性のパターンを示したが，明期に自発運動量およ び心拍数が一過性に増加する個体もみられた（Fig. 3 )。

3) 心拍数と自発運動量との相関: 心拍数と自発運 動量との相関をTable 2 に示した。八タネズミでは 5 例中 3 例が心拍数と自発運動量の間に有意な正の 


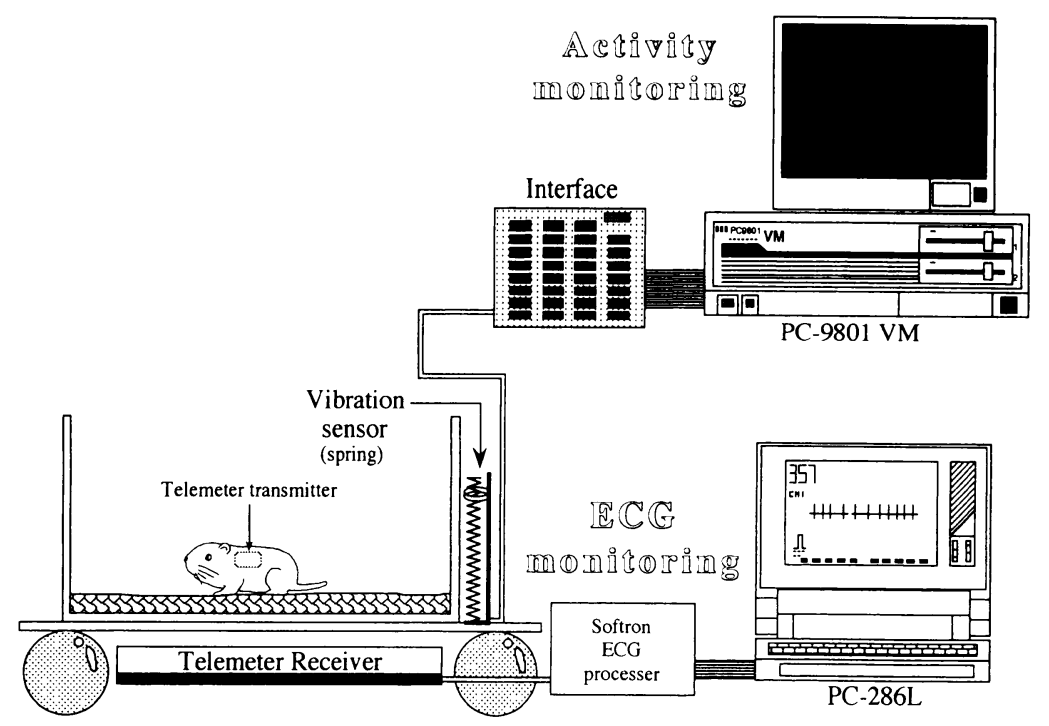

Fig. 1. Scheme of the recording system for measuring heart rate and locomotive activity by telemetry

Table 1. Heart rate (HR) of voles and mice in whole day, light period and dark period

\begin{tabular}{cccc}
\hline Voles & HR in whole day & HR in light p. & HR in dark p. \\
\hline \# V1 & $445 \pm 53$ & $439 \pm 51$ & $453 \pm 54^{*}$ \\
\# V2 & $493 \pm 41$ & $492 \pm 38$ & $494 \pm 44$ \\
\# V3 & $408 \pm 51$ & $395 \pm 42$ & $427 \pm 56^{*}$ \\
\# V4 & $448 \pm 47$ & $441 \pm 43$ & $457 \pm 50^{*}$ \\
\# V5 & $412 \pm 36$ & $414 \pm 35$ & $410 \pm 37$ \\
\hline Mean & $441 \pm 31$ & $436 \pm 33$ & $448 \pm 29$ \\
\hline N & $860 \sim 1147$ & $503 \sim 671$ & $357 \sim 476$ \\
\hline Mice & & & $679 \pm 64^{*}$ \\
\hline \# M1 & $651 \pm 68$ & $631 \pm 64$ & $662 \pm 58^{*}$ \\
\# M2 & $624 \pm 64$ & $597 \pm 53$ & $604 \pm 65^{*}$ \\
\# M3 & $570 \pm 72$ & $546 \pm 67$ & $648 \pm 32$ \\
\hline Mean & $615 \pm 34$ & $591 \pm 35$ & $475 \sim 476$ \\
\hline N & $1143 \sim 1146$ & $668 \sim 670$ &
\end{tabular}

Each value represents a mean \pm S.D. obtained from measurement for 3 (\#V1) or 4 days (\#V2 \# V5, \#M1 \#M3). * : Significantly different from HR in light period $(P<0.01) \quad \mathrm{N}$ : numbers of sampling every 5 min for $3-4$ days

相関 $(\mathrm{P}<0.01)$ を, 残る 2 例は有意な負の相関 $(\mathrm{P}<$ $0.01)$ を示した。

一方，マウスでは全例において心拍数と自発運動 量の間には有意な正の相関 $(\mathrm{P}<0.01)$ がみられた。
4) 心拍数りズムと自発運動りズムの周期性分析： 心拍数と自発運動量のそれぞれのリズムの周期性分 析の結果をTable 2 に示す。

ハ夕ネズミでは心拍数に 95 210 分の，自発運動 

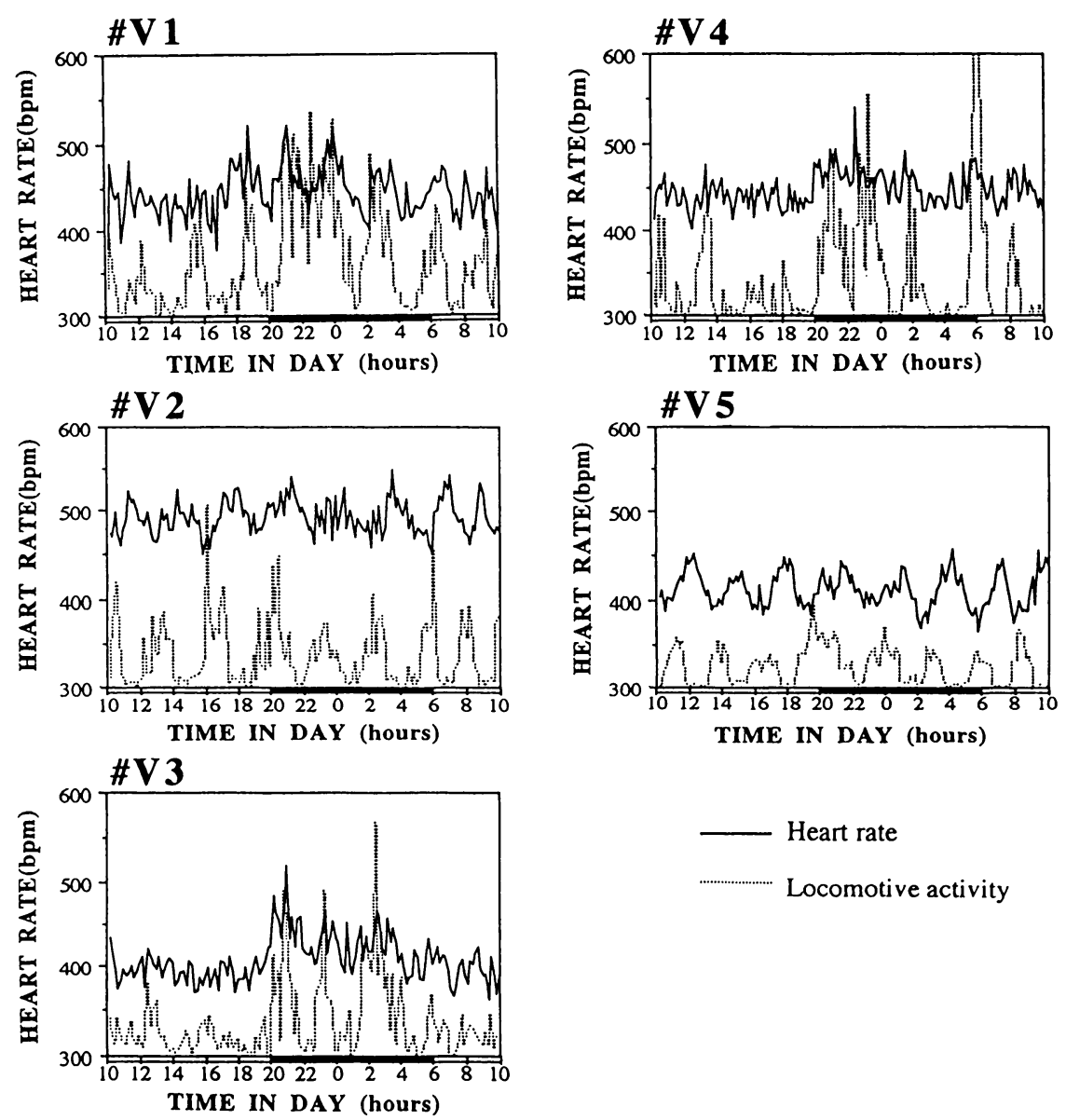

Fig. 2. Daily patterns of heart rate and locomotive activity in 5 voles from continuous measurements by telemetry for 3 (\#V 1) or 4 (\#V $2 \sim \# \mathrm{~V} 5)$ days. Ten min averages are employed as units. The black portion in the horizontal bar indicates the dark period.

量に160 210 分の周期性变動が認められた。各個体 ごとに両指標の周期を比較すると, \# V 1, \#V 2, \#V 3，\#V5の個体では心拍数と自発運動量のリズ ムの周期がほとんど同じであった。V 4 の個体では 心拍数りズムには 95 分の周期がみられ,一方自発運 動量にはその約 2 倍に当たる 210 分の周期が観察さ れた。

一方，マウスでは\#M 1 において心拍数変動に 85 分周期のリズムがみられたのみで，その他の例では 心拍数および自発運動量ともにウルトラディアンリ ズムに相当する短時間の周期性変動は認められな かった。
1)心拍数および自発運動量のリズムと両者の関連 性：ハ夕ネズミの心拍数には数時間周期の変動, す なわちウルトラディアンリズム (ultradian rhythm) が存在することが確認された。八タネズミのウルト ラディアンリズムは基本的に捸食リズムを反映して いると考えられている [7]。この際，休息期には睡 眠をとりながら胃内発酵によって食物中のセルロー スを分解し生体活動に必要なエネルギーを摂取して いると考えられる。

Table 2 に示したように，八タネズミではほとん どの個体で心拍数と自発運動量のリズムがほほ同じ 

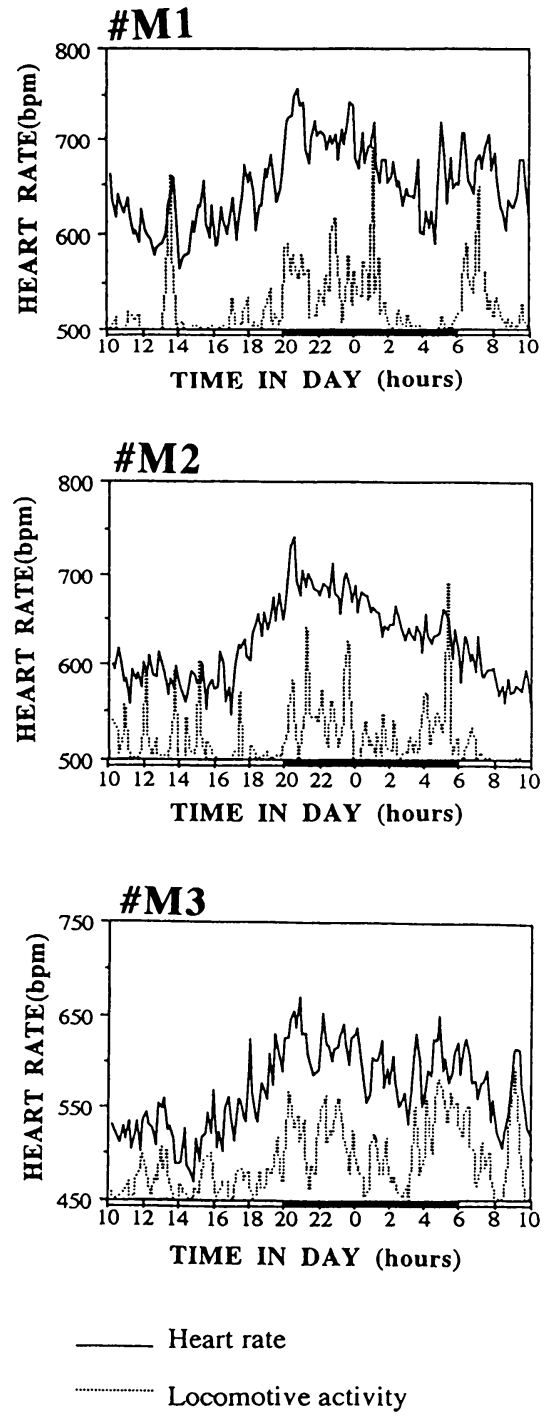

Fig. 3. Daily patterns of heart rate and locomotive activity in 3 mice from continuous measurements by telemetry for 4 days. Ten min averages are employed as units. The black portion in the horizontal bar indicates the dark period.

周期を有しており，両者の高い相関性が確認された。 5 例のうち 1 例は心拍数变動の周期が 95 分である のに対し, 自発運動量の周期は約 2 倍の 210 分を示 しており, 活動・休息リズムの 1 周期の間に, 心拍 数変動は 2 回の周期を持っていたと考えられた。総 じて, 自発運動量と心拍数の相関は全個体において 有意に高く $(\mathrm{P}<0.01)$, 自発運動のリズムと心拍数
Table 2. Relations between heart rate (HR) and locomotive activity (LA) in voles and mice

\begin{tabular}{lccc}
\hline \multirow{2}{*}{ Voles } & $\begin{array}{c}\text { HR \& LA } \\
\text { correlation } \\
\text { coefficients }\end{array}$ & HR & LA \\
\cline { 3 - 4 } \#V1 & $0.539 *$ & $185+$ & $190+$ \\
\#V2 & $-0.257 *$ & $180+$ & $180+$ \\
\#V3 & $0.632 *$ & $210+$ & $210+$ \\
\#V4 & $0.439 *$ & $95+$ & $210+$ \\
\#V5 & $-0.370 *$ & $160+$ & $160+$ \\
\hline Mice & & & \\
\hline \#1 & $0.556 *$ & $85+$ & - \\
\# M2 & $0.385 *$ & - & - \\
\# M3 & $0.731 *$ & - & - \\
\hline
\end{tabular}

* : Significantly higher in correlation coefficients $(\mathrm{P}<0.01)+$ : Significantly higher in the rhythmicity of heart rate and locomotive activity $(\mathrm{P}<0.01)$

のリズムとがほほ同一であることを意味している。

心拍数変動を自発運動と関連づけてみると, 活動 期に心拍数が増加する個体が 3 例（\#V 1, \#V 3， \#V 4) みられたのに対して, 逆に活動期に心拍数が 減少する個体も2 例（\#V 2, \#V 5 ）認められた。

一般に, 活動時には動物の酸素要求量が増大する ため，心拍数は增加する。ラットでもそれを轰付け る報告がある $[2,9,11]$ 。また今回のマウスの成績で も，心拍数と自発運動量の間には全例が有意な正の 相関 $(\mathrm{P}<0.01)$ を示していた。しかしながら, 本研 究では 2 例のハ夕ネズミにおいて，心拍数の增隇と 活動相との間に逆転した関係が認められたことはき わめて興味深い。

この 2 例とも暗期心拍数と明期心拍数の間に有意

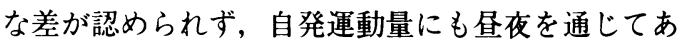
まり大きな変動が認められなかった。また今回の実 験ではケージの振動を計測して自発運動の指標とし ていたために，個体間での自発運動量の正確な比較 は困難であったが, この 2 例では一日の総自発運動 量が少なく，そのため心拍数を变動させる要因のう ち, 自発運動による心拍数増加の度合が小さく抑之 られ, 自律神経系の緊張度変化による心拍数の修飾 の方が大きく関与していたのではないかと考えられ た。このような心拍数変動の背景要因としては, 単 に全身の酸素要求が関与するのみならず，自律神経 中枢自体の周期的な活動变化の可能性も否定できな いと思われる。 
さらに, 覚醒期の自発運動の中には, 走行, 跳躍 行動等のエネルギー消費量が比較的多い活動や，探 索行動，グルーミング等のエネルギー消費量が比較 的少ない活動がある。心拍数に対する影響には活動 の質的な相違により大きな差異が生じるであろう。 今回の実験では自発運動の種類の弁別を行っていな いので，心拍数変動に対する自発連動の質的な関連 性については不明である。

2) ハ夕ネズミとマウスの相違点：哺乳類において は，一般に成熟動物の体重ないし心茂重量と心拍数 との間には負の相関が成り立つことが知られている [10]。しかし, 今回の研究結果では八タネズミとマ ウスはほほ同程度の体重を有しているにもかかわら ず，八夕ネズミの心拍数はマウスのそれよりもかな り少ないことが明らかとなった。今回我々の研究で はハ夕ネズミの心臓重量と体重との相関を明らかに していないが, Bradreyら [1] は，右室がマウスに 比べてやや小さいことを除けば，他の部位の体重に 対する比率はハ夕ネズミ，マウス間ではほとんど差 がないことを明らかにしている。

またBradleyらはM.ochrogaster (プレーリーハ夕 ネズミ）とマウスを用いた実験でM.ochrogasterの 心拍数と呼吸数が，同程度の体重および代謝率を有 するマウスよりも少ないことを報告している $[1]$ 。 彼らによればM.ochrogasterの心拍数は 499 回/分, マウスの心拍数は 676 回/分と本実験における結果 と類似していた。

このようにハ夕ネズミの平均心拍数は, 明期, 暗 期を通じて常にマウスのそれよりも少ないことが明 らかとなったが, 同時にハ夕ネズミはマウスに比し て明期と暗期の平均心拍数の差が小さいことも分 かった。これはすなわち，八夕ネズミの自発運動り ズムがマウスの様なノクターナルリズムよりもウル トラディアンリズムによる支配を大きく受けている ことを反映しているものと思われる。

以上のようにハタネズミとマウスとでは，ほほ同 体重の小型觢歯類であるにもかかわらず，心拍数や 自発運動における特性が大きく異なることが明らか となった。この特性には八夕ネズミが草食性である ことが深くかかわっているものと思われる。この推 論は, Hansson [4]によれば，ハ夕ネズミとほほ同 体重であっても種子食性であるPeromyscus属は, 八 タネズミほどの明確なウルトラディアンリズムを示 さない事実や，またHoogenboom [5] らが，八夕ネ
ズミにラット用の餌を給与したところ明期のウルト ラディアンリズム様の捸食行動が消失したと報告し ていることからも裏付けられる。

以上述べたように，八タネズミの心拍数にもウル トラディアンリズムが存在することが確認された が, その基本的要因としてハ夕ネズミの食性が関与 していることが示唆された。

\section{要約}

八タネズミの心拍数および自発運動の日内変動を 無麻酔, 無拘束下で記録し, マウスのそれらと比較 した。ハ夕ネズミの 24 時間の平均心拍数はマウスよ りも少ない傾向にあった。八夕ネズミの平均心拍数 は明期および暗期の間で顕著な差異が認められな かった。また大部分の個体で自発運動は暗期のみな らず明期にも活発であることが観察された。それに 対して，マウスでは全例で暗期の平均心拍数が明期 よりも有意に多く, 自発運動も明瞭な夜行性を示し た。ハ夕ネズミの心拍数および自発運動量の変動を 詳細に検討すると，心拍数では 95 210 分周期，自 発運動では 160２10 分周期のウルトラディアンリ ズムが認められた。ウルトラディアンリズムによる 心拍数変動の大きさは明期と暗期の間の差よりも顕 著であった。一方, マウスでは 85 分周期の心拍数り ズムが 3 例中 1 例に認められたのみであった。また 八タネズミでは心拍数変動の増堿のピークが活動期 に一致する個体と休息期に一致する個体の 2 種類の パターンが区別された。それに対してマウスでは全 例で心拍数の増加は活動期に一致した。以上の成績 から，八タネズミの心拍数变動は自発運動同様にウ ルトラディアンリズムを有することが確認された。

八夕ネズミを提供していただきました日本獣医畜産大学獣 医畜産学部獣医生理化学教室の大木与志雄教授および菅原盛 幸博士に深く感謝申し上げます。

\section{文献}

[1] Bradley, S.R. and Jorgensen, D.D. (1978). Of mice and voles: comparative cardio-respiratory vari. ables. Physiologist, 21, 12.

[2] Büttner, D. and Wollnik, F. (1982). Spontaneous short-term fluctuations in the daily pattrn of heart rate, body temperature and locomotor activity in the laboratory rat. Lab. Anim., 16, 319-326.

［3］後藤信男(1989)。八タネズミ。実験動物の生物学的特性 
データ, 田嶋嘉雄 (監修), pp.520-525.ソフトサイエン 又社, 東京,

[4] Hansson, L. (1971). Small rodent food, feeding and population dynamics. Oikos, 22, 183-198.

[5] Hoogenboom, I., Daan, S., Dallinga, J. H., and Schoenmakers, M. (1984) Seasonal change in the daily timing of behaviour of the common vole, Microtus arvalis. Oecologia, 61, 18-31.

［6］工藤 博・大木与志雄(1982)。草食性実験動物としての 本邦産ハ夕ネズミ(Microtus montebelli Milne-Edwar ds) とハンガリー産ハタネズミ(Microtus arvalis Pal. las）の有成および繁殖について. 寒験動物, 31, 175-183.

[ 7 ] Lehmann, U. and Sommersberg, C.W. (1980). Activity patterns of the common vole, Microtus arvalis -autonomic recording of behaviour in an enclosure. Oecologia, 47, 61-75.

[ 8 ] Madison, D.M. (1985). Activity rhythms and spacing. In Biology of New World Microtus ., pp 373-419, Tamarin, R. H. (ed.), Amer. Soc. Mammalogist,
Pennsylvania.

[9] Meinrath, M. and D'Amato, M. R. (1979). Interrelationships among heart rate, activity, and body temperature in the rat. Physiol. Behav., 22, 491-498.

[10］澤崎 坦 (1980). 比較心謨学, pp 1-14, 朝倉書店, 東京.

[11] Schlatter, J . and Zbinden, G. (1982) . Heart rate- and ECG-recording in the rat by biotelemetry. Arch Toxicol., suppl. 5, 179-183.

[12] Sokolove, P.G. and Bushell, W.N. (1978). The chi square periodogram : its utility for analysis of circadian rhythms. J. theor. Biol., 72, 131-160.

［13］菅原盛幸・桐谷礼子・大木与志雄 (1978)。草食性八夕衣 ズミ(Microtus arvalis Pallas)の生物学的並びに血液生 化学的特性. 実験動物, 36, 1-9.

[14] Tamarin, R. H. (ed.) (1985). Biology of New World Microtus. Amer. Soc. Mammalogist, pp 1-893, Pennsylvania. 